\title{
PENERAPAN TEKNOLOGI PEMBUATAN PIA SEBAGAI MAKANAN BERSUMBER DAYA ALAM LOKAL DARI SERABUT BUAH LONTAR UNTUK MENINGKATKAN EKONOMI MASYARAKAT PULAU ROTE
}

\author{
I N Widiartha Mahayasa ${ }^{1}$, P.G.M Widyaswari Mahayasih ${ }^{2}$, Nyoman Sirma ${ }^{3}$, Kartiwan. $\mathrm{S}^{4}$ \\ ${ }^{1}$ Fakultas Pertanian Universitas Nusa Cendana Kupang \\ ${ }^{2}$ Fakultas Ilmu-ilmu kesehatanUniversitas Esa Unggul Jakarta \\ Email: dumek_mahayasa@yahoo.co.id \\ ${ }^{3}$ Fakultas Pertanian Universitas Nusa Cendana Kupang \\ ${ }^{4}$ Dosen Poli Tani Negeri Kupang
}

\begin{abstract}
ABSTRAK
Kelompok Oo Daro dan kelompok Ita Esa yang berada di Kecamatan Rote Barat Daya dan Kecamatan Lobalaen Kabupaten Rote-Ndao Nusa Tenggara Timur (NTT) telah umum melakukan usaha pengolahan produk dari buah lontar, yaitu gula cair dari nira buah lontar. Gula ini sangat digemari oleh masyarakat, bahkan sampai ke luar daerah. Disamping nira dari buah yang umum digunakan, buah lontar masak juga dapat diolah menjadi produk dengan nilai jual yang baik, yaitu menjadi pia buah lontar. Pengolahan buah lontar masak menjadi berbagai jenis makanan (kue), bagi masyarakat Rote, merupakan suatu hal (teknologi) yang masih baru. Selama ini buah yang telah masak lebih banyak dibuang begitu saja. Oleh karena itu, masyarakat dari kelompok Oo Daro dan kelompok Ita Esa sangat antusias dalam mengikuti kegiatan pelatihan yang diadakan. Kegiatan dilakukan selama 2 hari. Hasil kegiatan menunjukkan bahwa kedua kelompok ini telah memahami proses pengolahan buah lontar masak menjadi pia dan dimanfaatkan sebagai salah satu sumber pendapatan mereka
\end{abstract}

Kata kunci: Serabut, Buah lontar, pia, kue

\section{PENDAHULUAN}

Pulau rote merupakan satu dari 1050 pulau yang terdapat di Provinsi Nusa Tenggara Timur (NTT). Kabupaten Rote-Ndao terdiri dari lima (5) Kecamatan, yaitu Kecamatan Rote Barat Laut, Kecamatan Rote Barat Daya, Kecamatan Baa, Kecamatan Lobalain, dan Kecamatan Rote Tengah. Kabupaten Rote merupakan pemekaran dari Kabupaten Kupang, sehingga diperlukan pembinaan dan penataan bagi masyarakatnya dalam mempersiapkan menjadi daerah otonom baru yang mandiri.

Letak pulau Rote dari ibukota provinsi NTT atau dari Universitas Nusa Cendana diperkirakan sekitar $150 \mathrm{~km}$. Untuk mencapai pulau Rote, dapat ditempuh dengan menggunakan kapal feri melalui laut dengan lama perjalanan kurang lebih selama 6 jam, atau dapat pula dengan menggunakan pesawat (kapasitas 12 orang) dengan waktu tempuh sekitar 30 menit atau dengan menggunakan kapal cepat sekitar 2 jam.

Pulau Rote merupakan salah satu pulau dari beberapa Pulau di NTT yang memiliki potensi dengan populasi pohon "Tuak" (Lontar) terbanyak disamping Pulau Sabu dan Pulau Timor (Mahayasa, 1995). Diperkirakan 30\%-40\% dari jumlah populasi lontar ada di NTT terdapat di Rote. Sayangnya, masyarakat di Kabupaten Rote belum secara maksimal memanfaatkan potensi yang luar biasa dari pohon lontar. Hal ini karena ketidak tahuan masyarakat tentang apa yang dapat dikembangkan dari lontar. Selama ini lontar hanya dikelola sebatas produksi gula cair dari nira.

Dalam kehidupan sehari-hari, masyarakat di Kabupaten Rote sangat erat hubungannya dengan pohon tuak (lontar) ini (Mahayasa, 2007). Hampir disemua lini kehidupan tidak terlepas dari organ dan bagian dari pohon tuak (Mahayasa, 1995). Sebagai contoh, dalam segi sosial budaya, religis (keagamaan), dan juga dalam kedukaan, dimana batang pohon ini biasanya dimanfaatkan sebagai peti mati, peralatan dapur dan bahan makanan juga dapat diperoleh dari pohon lontar. Baik dengan mengolah akar, batang, daun, maupun buahnya. Saat tiba musim paceklik, pohon lontar dapat menjadi salah satu sumber bahan pangan sehingga masyarakat dapat terhindar dari kerawanan pangan. 
Kelompok usaha (KUB) Oo daro dan Ita Esa, merupakan dua kelompok usaha kecil yang selama ini memproduksi gula lontar sebagai mata pencaharian pokok dalam menunjang perekonomian mereka. Gula ini diolah dari nira lontar. Produksi rata-rata perharinya diperkirakan sekitar 5 liter gula, dengan demikian jika selama sebulan dikerjakan secara terus menerus, maka dapat dihasilkan 450 liter perbulan, dengan harga jual per liter Rp 10.000. Berdasarkan data ini, satu kelompok dapat memperoleh penghasilan kotor Rp 4.500 .000 per bulan. Bila dalam satu kelompok terdapat 5 orang anggota, maka pendapatan ini masih dirasa kurang.

Tingkat pendidikan anggota kelompok ini adalah dari yang tidak bersekolah sampai dengan tamat SMP, berumur dari 23 tahun sampai dengan 50 tahun, dengan rasio pekerja wanita dan laki-laki adalah 6:4. Umumnya, anggota kelompok berasal dari keluarga sendiri, sehingga sistem manajemen keuangan belum di atur dengan baik dan masih sebatas untuk kebutuhan sehari-harinya saja. Proses pengolahan nira buah lontar menjadi gula cair ini dilakukan secara turun-temurun berdasarkan adat istiadat kebiasaan, sehingga proses pengembangan bahan lain menjadi minim.

Selama ini, gula cair yang telah diproduksi lebih banyak dipasarkan ke Pulau Timor (Kupang), sedangkan, untuk tingkat lokal jarang diperjual belikan dan hanya dikonsumsi sendiri karena hampir semua masyarakat di Kabupaten Rote rata-rata memproduksi gula sejenis. Sementara itu, kehidupan masyarakat di Kabupaten Rote ini, khususnya kelompok ini masih di bawah rata-rata (masih kurang), sehingga diperlukan bantuan untuk meningkatkan perekonomian masyarakat melalui pemanfaatan komoditi alami daerah. Pulau Rote merupakan salah satu pulau terkering di NTT dengan sumber air yang ada, maka akan sulit apabila harus dilakukan cocok tanam tanaman baru di bidang pertanian. Oleh karena itu, penting untuk dapat memanfaatkan potensi alam yang ada, terutama dari pohon lontar yang sudah banyak tumbuh di Pulau Rote.

Selain nira dari pohon lontar yang dapat diolah menjadi gula cair, terdapat bagian lain dari pohon lontar yang ternyata dapat dikembangkan menjadi bahan makanan yang mempunyai nilai jual tinggi apabila dikembangkan, yaitu buah lontar masak. Minimnya pengetahuan masyarakat di Kabupaten Rote mengenai cara pengolahan buah lontar masak menyebabkan buah lontar yang telah masak tersebut cenderung tidak dimanfaatkan dan terbuang begitu saja. Padahal, dengan sistem pengolahan yang tepat dan baik, pulp dari buah lontar masak dapat diolah menjadi berbagai macam produk pangan seperti selai, kerupuk, dan dodol yang jelas memiliki nilai jual tinggi.

Dari hasil pengamatan di lapangan yang intensif itulah, timbul pemikiran tim untuk melakukan kegiatan pelatihan pengolahan buah lontar (masak) untuk diolah menjadi pia (kue). Melalui teknologi yang sangat sederhana ini, diharapkan akan memberikan tambahan pemasukan bagi kelompok dan umumnya bagi masyarakat di Pulau Rote.

\section{METODE PENELITIAN}

Metode yang digunakan dalam pelatihan ini yaitu melalui pemberian materi dan praktek langsung melalui demo langsung pembuatan pia. Demo yang dilakukan yaitu dimulai dari bagaimana cara pemilihan buah yang baik, proses mendapatkan bahan baku pia, pemasakan pia, pembungkusan pia, hingga proses pengemasan pia buah lontar. Alur kegiatan dapat dilihat pada Gambar 1. 


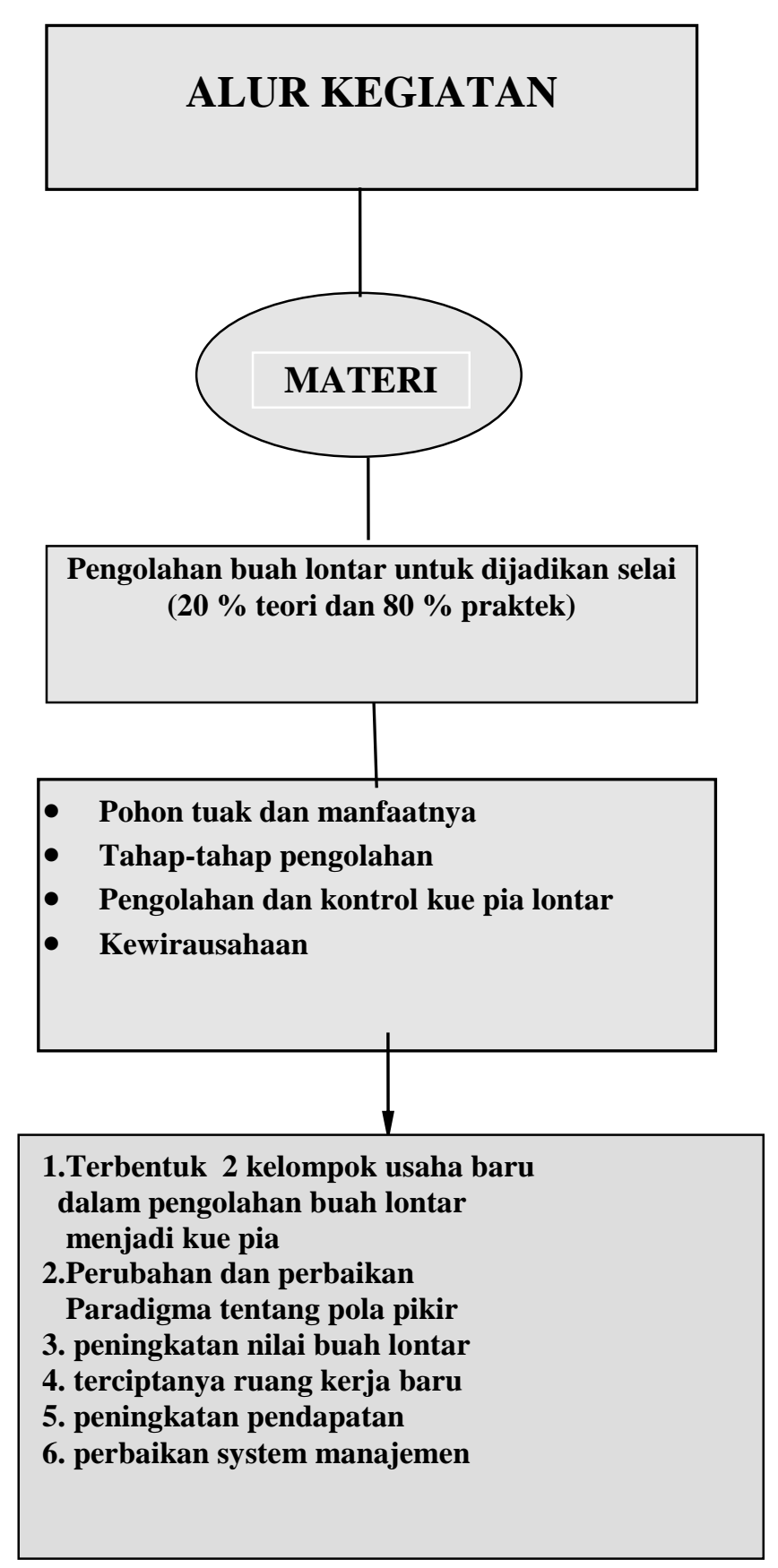

Gambar 1. Alur Kegiatan

\section{HASIL DAN PEMBAHASAN}

Kegiatan ini telah dilakukan dan dapat berjalan dengan baik. Kegiatan dilakukan melalui dua tahap, tahap awal adalah melalui pemberian materi kepada mitra mengenai hal-hal yang perlu diketahui. Sedangkan tahap ke dua adalah tahap pelatihan, yang meliputi demonstrasi cara membuat Pia yang dilanjutkan dengan proses produksi secara langsung oleh kelompok. Pelatihan dilakukan di dua kelompok, yaitu kelompok Oo Daro dan kelompok Ita Esa, Kecamatan Rote Barat Laut kabupaten Rote-Ndao, dengan jumlah anggota kelompok sebanyak 10 orang. Namun, jumlah total peserta yang mengikuti kegiatan ini mencapai 25 orang, yang berasal dari masyarakat dan tim penggerak PKK Kabupaten. Tahap-tahap yang dilakukan pada saat kegiatan adalah: 
a. Tahap Penyuluhan: Sebelum masuk pada kegiatan pelatihan secara langsung, masyarakat diberikan penyuluhan dan pencerahan mengenai beberapa materi penting yang harus diketahui, seperti pengenalan tentang tanaman lontar, pemasaran produk, dan kebersihan dalam proses produksi. Dalam proses ini dilakukan pula diskusi/tanya jawab.

b. Tahap demonstrasi: sebelum dilakukan praktek langsung dalam proses pengolahan, sebelumnya dilakukan demonstrasi oleh para pelatih bagaimana teknik produksi yang baik. Tahap ini juga dilakukan diskusi/tanya jawab.

c. Tahap pelatihan aktif: tahap ini peserta secara aktif dengan bahan dan alat yang ada langsung melakukan proses produksi kue pia. Pelatihan ini dilaksanakan dengan bimbingan dari para pelatih sehingga seluruh peserta dapat mencoba dan menguasai teknologi yang diajarkan. Kegiatan ini meliputi produksi, pembungkusan dan pengemasan dalam kemasan yang telah disediakan.

d. Pemasaran produk. Dalam proses pemasaran produk yang telah dibuat, terdapat beberapa kendala, dimana produk pia buah lontar masih tergolong baru di Kabupaten Rote, sehingga masih sulit diterima oleh masyarakat. Oleh karena itu, proses pemasaran akan dilakukan secara bertahap dengan sebagaian produk akan dipasarkan oleh tim di Kupang sebagai Ibu Kota Propinsi NTT.

Hasil Analisis Kandungan Bahan Kue Pia

Tabel 1. Analisis Kandungan Senyawa antioksidan pada bahan Dasar/pulp

\begin{tabular}{|c|c|c|}
\hline No & $\begin{array}{c}\text { Jenis Senyawa } \\
\text { Antioksidan }\end{array}$ & $\begin{array}{c}\text { Konsentrasi } \\
(\mathrm{mg} / 100 \mathrm{~g} \\
\text { bahan })\end{array}$ \\
\hline 1 & Karoten & 61,16 \\
\hline 2 & Vitamin C & 46,42 \\
\hline 3 & Polifenol & 31,92 \\
\hline 4 & Antosianin & 5,39 \\
\hline
\end{tabular}

Sumber: Rubak dkk: 2009

Tabel 2. Kandungan Gizi Bahan Dasar kue Pia

\begin{tabular}{|c|c|c|}
\hline No & Zat Gizi & Kandungan (\%) \\
\hline 1 & Kadar air & 91,00 \\
\hline 2 & Mineral & 0,44 \\
\hline 3 & Lemak & 2,42 \\
\hline 4 & Protein & 1,89 \\
\hline 5 & Karbohidrat & 4,25 \\
\hline
\end{tabular}

Sumber: Rubak dkk; 2009

Masih banyak lagi manfaat yang dapat diperoleh dari buah lontar (masak), oleh sebab itu mengingat jumlah bahan baku yang ada masih sangat banyak, maka penelitian perlu lebih digiatkan lagi untuk mendapatkan produk-produk baru dari hasil olahan buah lontar (masak).

Diharapkan pula kedepannya dapat dilakukan diversivikasi produk, mengingat tingkat pemanfaatan bahan dasar buah lontar yang jumlahnya sangat banyak belum mencapai tingkat yang maksimal di dalam pengelolaannya. Karena itu perlu dilakukan pemberian pelatihan kepada kelompok-kelompok masyarakat. 


\section{KESIMPULAN}

Kesimpulan yang dapat ditarik setelah dilakukan pelatihan kegiatan ini adalah:

1. Kelompok UKM Oo Daro dan Ita Esa telah dapat memproduksi buah lontar menjadi Pia

2. Ketertarikan kelompok dalam menyerap ilmu yang diberikan sangat antusias (tingkat kehadiran $100 \%)$.

3. Produk yang telah dihasilkan telah dipasarkan, namun masih ditingkat lokal. Kedepannya akan dipasarkan di tingkat ibu kota provinsi. Diharapkan produk lontar akan menjadi salah salah satu jenis panganan unggulan bagi masyarakat Rote mengingat bahan baku yang begitu banyak (30$40 \%$ dari populasi lontar NTT) .

4. Buah lontar masak yang dulunya kurang diperhatikan, saat ini semakin dicari dan memiliki nilai tambah.

5. Tingkat pendapatan kelompok yang bertambah setiap bulannya hingga berkisar Rp 2.545.000.

6. Bahan dasar pia, yaitu buah lontar masak memiliki kandungan gizi, vitamin, dan kandungan antioksidan yang cukup tinggi

\section{REFERENSI}

Apriyanto, 1989. Petunjuk Laboratorium: Analisis Pangan. Bogor.

Badan Pusat Statistik. (2011). Kabupaten Rote-Ndao dalam Angka.

Baliwati Y.F, Khiomsan A., Dwariani M. 2000. Pengantar Pangan dan Gizi. Rineka Cipta „Jakarta.

Fox, J.J., (1997). Harvest of The Palm. Ecologycal Change in Eastern Indonesia. Havard Press, Cambrige, London.

Kiuk, Z R. 2003. Laporan Luas dan populasi tanaman Lontar di Pulau Rote. Seksi Rehabilitasi dan Perlindungan Tanaman Perkebunan. Rote-Ba'a, Prop NTT.

Kupang pos (2009). Tingkat Kemiskinan di Nusa Tenggara Timur Masih Cukup Tinggi. Kupang Pos edisi 12 Feb Hal: 6. 2009.

Mahayasa, I N.W. 1995. Lontar dan Permasalahannya di Nusa Tenggara Timur. Fakultas Pertanian Universitas Nusa Cendana.

Mahayasa,I N.W. 1998 a . Desain Teknologi Pemanfaatan Buah Lontar Menjadi Sirup. (Suatu Karya Teknologi). Fakultas Pertanian Universitas Nusa cendana, Kupang.

Mahayasa, I N.W. 1999. desain Teknologi Pemanfaatan Buah Lontar Menjadi Selei. (Suatu Karya Teknologi). Fakultas Pertanian Universitas Nusa Cendana, Kupang.

Mahayasa, I N.W, 2000. Desain Teknologi Pemanfaatan Buah Lontar Menjadui Dodol. (Suatu Karya Teknologi). Fakultas Pertanian Universitas Nusa Cendana, Kupang.

Mahayasa, I N.W. 2000. Lontar. Salah satu Tanaman Unggulan Masyarakat Nusa Tenggara Timur. Fakultas Pertanian Universias Nuca Cendana, Kupang.

Mahayasa, I N.W. 2004. Desain Teknologi Pemanfaatan Serabut Buah Lontar Menjadi Keset dan Barang Kerajinan Lainnya. Fakultas Pertanian Universisa Nusa Cendana, Kupang. 
Rubak, Y.T; H.J.D. Lalel; I N.W. Mahayasa., 2009. Karakterisasi dan pemanfaatan potensi pulp buah siwalan sebagai sumber zat tambahan makanan alami: antioksidan, zat pewarna, dan aroma.

Widyatmika, M. 1989. Penelitian Sosial Ekonomi Pemanfaatan Lontar di Pulau Rote dan Sabu. Departemen Kehutanan dan Pengembangan Kehutanan Proyek Penelitian Kehutanan di Nusa Tenggara Timur 